\title{
Penerapan Particle Swarm Optimization Pada Feedforward Neural Network Untuk Klasifikasi Teks Hadis Bukhari Terjemahan Bahasa Indonesia
}

\author{
Muhammad Ghufran, Adiwijaya, Said Al Faraby \\ Fakultas Informatika, Universitas Telkom Bandung, Indonesia \\ Email: ${ }^{1}$ muhghufran@ @student.telkomuniversity.ac.id, ${ }^{2}$ adiwijaya@telkomuniversity.ac.id \\ ${ }^{3}$ saidalfaraby@telkomuniversity.ac.id
}

\begin{abstract}
Abstrak
Hadis merupakan sumber hukum Islam kedua setelah Al-Quran dan dijadikan sebagai pedoman hidup bagi umat islam. terdapat banyak hadis yang telah diriwayatkan salah satunya riwayat Bukhari. Penelitian ini bertujuan untuk membangun model yang dapat melakukan klasifikasi teks hadis Bukhari terjemahan bahasa Indonesia. Topik ini dipilih untuk membantu masyarakat dalam memahami makna informasi yang terdapat didalam hadis berupa informasi yang menganjuran, melarangan, atau hanya sebatas informasi saja. Algoritma Backpropagation (BP) merupakan teknik yang umum digunakan untuk melatih Feedforward Neural Network (FNN) dalam proses klasifikasi karena memiliki akurasi yang baik khususnya dalam klasifikasi teks. Tetapi BP memiliki kelemahan yaitu relatif lambat untuk mencapai konvergen dan terjebak dalam local minimum. Untuk mengatasi hal tersebut, algoritma Particle Swarm Optimization (PSO) digunakan untuk mempercepat mencapai konvergen dan mencari nilai global minimum. Tujuan dari pengujian ini untuk melihat kemampuan PSO dalam melatih bobot dan bias pada FNN. Hasil pengujian pada 1000 data hadis menunjukkan model PSO-FNN dengan proses stemming mendapatkan akurasi $88.5 \%$ sedangkan tanpa proses stemming mendapatkan akurasi 88.57\%. Sementara itu, hasil pengujian perbandingan antara PSOFNN dengan BP-FNN, hasil menunjukkan bahwa PSO-FNN mendapatkan akurasi sebesar $88.57 \%$ lebih rendah $0.93 \%$ dibandingkan BP-FNN yang memperoleh akurasi sebesar $89.5 \%$.
\end{abstract}

Kata kunci: hadis, particle swarm optimization, backpropagation, feedforward neural network, klasifikasi teks, pemilihan fitur, multi-label

\begin{abstract}
Hadith is the second source of Islamic law after Al-Qur'an and used as a guide for Muslims life. there are many hadith which has been narrated, one of them is Bukhari history. This research aims to build a model that can classify Bukhari hadith translation of Indonesian language. This topic is chosen to assist the public in understanding the meaning of the information that contained in the hadith, in the form of advocacy information, prohibitions or just information. The Backpropagation Algorithm (BP) is the general technique that used to train the Feedforward Neural Network (FNN) in classification process cause it has good accuracy for text classification. But, BP has a weakness that is relatively slow to reach convergent and stuck in local minimum. To overcome this, the Particle Swarm Optimization (PSO) algorithm is used to speed up convergence and find the minimum global value. The purpose of this test is to see the PSO's ability to train the weight and refraction of FNN The result of this research on 1000 hadith data show that model PSO-FNN with stemming process get $88.5 \%$ accuracy while without stemming process get $88.57 \%$ accuracy. Meanwhile, the result of comparative test between PSO-FNN with BP-FNN, the result shows that PSO-FNN get accuracy equal to $88.57 \%$ which is lower $0.93 \%$ than BP-FNN which has $89.5 \%$ accuracy.
\end{abstract}

Keywords: hadith, particle swarm optimization, backpropagation, feedforward neural network, text classification, feature selection, multi-label.

\section{PENDAHULUAN}

Hadis berasal dari bahasa Arab "Hadatha" yang berarti berita dan cerita atau bisa juga disebut sunnah, yang adalah perkataan, perbuatan, ketetapan dan persetujuan dari Nabi Muhammad yang dijadikan pedoman khususnya untuk kaum muslim di dunia. Hadis menjadi sumber hukum islam kedua setelah Al-Qur'an. Terdapat banyak kitab hadis yang ada di dunia, salah satu kitab hadis yang terkenal adalah Shahih Al-Bukhari karena dianggap sebagai kitab yang paling ontentik.

Saat ini, perkembangan teknologi tumbuh secara signifikan, salah satunya yang lagi tren adalah manfaat teknologi pengenalan ucapan untuk masyarakat dalam belajar pengucapan bahasa arab yang benar contohnya seperti belajar pengucapan huruf Hijaiyah [1]. Selain itu, dampak teknologi di jaman era digital membuat setiap informasi dapat ditemukan dengan mudah di internet. Tidak terkecuali hadis, Banyak data hadis dalam bentuk digital telah tersebar, sehingga memudahkan masyarakat untuk mempelajari ilmu islam yang terdapat dalam hadis. Setiap hadis memiliki informasi yang berbeda-beda. terdapat hadis yang menganjurkan untuk berbuat kebaikan, ada juga yang melarang, dan ada yang hanya memberikan informasi atau cerita yang telah terjadi pada sejarah islam. Untuk mengetahui sifat yang dimiliki pada setiap hadis dibutuhkan sebuah model sistem yang dapat mengidentifikasi apakah hadis tersebut merupakan anjuran, larangan, atau hanya sebatas informasi saja.

Akan tetapi tidak semua hadis hanya memiliki satu sifat saja, terdapat banyak hadis yang sifatnya lebih dari satu bahkan memiliki ketiga sifat tersebut. sehingga dibutuhkan model klasifikasi yang mampu mengelompokan hadis lebih dari satu sifat.

Dari latar belakang tersebut penulis membuat model klasifikasi multi-label yang memungkinkan setiap hadis memiliki lebih dari satu sifat. Hadis yang digunakan sebanyak 1000 data hadist Bukhari yang telah diberi 
label untuk membantu proses pembelajaran sistem. Information gain digunakan sebagai seleksi fitur untuk memilih fitur-fitur yang hanya berhubungan dengan setiap kelas. Selanjutnya model klasifikasi Feedforward Neural Network (FNN) yang bobot dan biasnya dilatih menggunakan metode Particle Swarm Optimization (PSO) digunakan untuk melakukan klasifikasi terhadap data yang telah diseleksi pada tahap sebelumnya. Hasil dari klasifikasi berupa label kelas dari masing-masing data.

Pada penelitian ini, penulis menggunakan dataset sebesar 1000 data hadis terjemahan bahasa Indonesia dari hadis Bukhari dengan tiga label yaitu anjuran, larangan, dan informasi. setiap data memungkinkan memiliki lebih dari satu label. selain itu, metode evaluasi yang digunakan untuk mengukur performasi sistem yaitu hamming loss yang merupakan salah satu metode evaluasi yang umum digunakan untuk pengujian multi-label, metode ini menghitung nilai error rate dari hasil klasifikasi.

Terdapat beberapa bagian selanjutnya pada jurnal ini, antara lain: Pada bagian kedua, terdapat studi terkait penelitian yang telah dilakukan sebelumnya. Pada bagian ketiga, akan dijelaskan alur dan model sistem yang akan dibangun untuk klasifikasi teks hadis bukhari terjemahan bahasa Indonesia dengan menggunakan Feedforward Neural Network (FNN) yang bobot dan biasnya dilatih menggunakan Particle Swarm Optimization (PSO). Pada bagian keempat, pemaparan hasil pengujian dan analisis dari hasil yang telah didapatkan. Pada bagian terakhir, dijelaskan kesimpulan yang didapatkan dari penelitian ini.

\section{TEORITIS}

Terdapat banyak penelitian tentang klasifikasi teks dengan memanfaatkan pendekatan machine learning, baik itu dalam bahasa inggris, arab, ataupun indonesia. Salah satu penelitian yang memanfaatkan machine learning pada klasifikasi teks adalah penelitian yang dilakukan oleh Al-Kabi [2], dengan bantuan teknik TF-IDF yang mengelompokkan hadis Bukhari menjadi kedalam 8 bentuk kelas yaitu "Knowledge", "Praying”, "Eclipse”, "Call to Prayer", "Faith", "Good Manners", "Fasting", dan "Almsgiving". Dalam penelitian tersebut hasil akurasi sangat dipengaruhi oleh preprocessing stopword dan stemming, rata-rata akurasi yang didapat adalah sebesar $83.2 \%$.

Penelitian lain tentang klasifikasi teks dilakukan oleh Harrag F [3] dengan menggunakan tiga metode stemming yaitu Root-Based stemming, Light-Stemming, dan Dictionary-Lookup stemming, untuk meningkatkan efektifitas dan performansi dari hasil klasifikasi teks. Pada penelitiannya, Artificial Neural Network (ANN) digunakan sebagai classifier karena memiliki kelebihan dapat menangani masalah linear dan non-linier untuk kategorisasi teks dan penggolongan linear dan non-linier dapat mencapai hasil yang baik [3]. Selain ANN, Support Vector Machine (SVM) juga digunakan dalam penelitian tersebut karena SVM merupakan model statistik yang memiliki kemampuan powerful dalam menangani set fitur yang sangat besar. Hasil dari penelitian tersebut, proses stemming digunakan sebagai feature reduction dalam memilih fitur yang akan digunakan dan mendapatkan hasil performansi sebesar 94\% menggunakan F1 Measure dengan Macro-Average.

Selain itu, penelitian tentang klasifikasi teks dalam bahasa indonesia juga pernah dilakukan oleh Eliza J [4] dengan melakukan klasifikasi teks hadis Bukhori terjemahan bahasa Indonesia kedalam tiga kelas hadis, yaitu hadis anjuran, hadis larangan, dan hadis informasi. Dalam penelitiannya klasifikasi teks hadis berdasarkan model unigram dengan menggunakan Artificial Neural Network (ANN), dan TF-IDF sebagai teknik untuk mendapatkan bobot nilai pada setiap kata. Pada pengujiannya menghasilkan performansi sebesar $85 \%$. Disisi lain, penelitian serupa dilakukan oleh Andina K [5] pada tahun 2017 dengan menggunakan Support Vector Machine (SVM), pada penelitian tersebut data di split menjadi data latih dan data uji menggunakan teknik K-Fold. Hasil rata-rata performansi yang didapatkan pada pengujian tersebut sebesar $88 \%$.

Disisi lain, Asriyanti Indah Pratiwi [6] melakukan penelitian tentang klasifikasi teks untuk sentimen analisis dalam movie review. Menemukan pemilihan fitur dan klasifikasi yang bagus merupakan tantangan tersendiri untuk mendapatkan hasil yang optimal. Pada penelitian ini, information gain digunakan sebagai feature selection dan classifier. Pemilihan fitur dan klasifikasi berdasarkan informasi yang dibutuhkan untuk menangani jumlah fitur yang besar agar klasifikasi lebih optimal, sekitar 90\% fitur yang tidak diperlukan dihilangkan dan mendapatkan akurasi rata-rata sebesar $96 \%$. Hasil tersebut merupakan kinerja terbaik sejauh ini.

Pada kasus klasifikasi teks multi-label, terdapat beberapa penelitian yang telah dilakukan. Salah satunya yang dilakukan oleh Min-Ling Zhang dan Zhi-Hua Zhou [7] pada tahun 2006 terkait penelitian tentang klasifikasi teks multi-label. Metode yang digunakan pada penelitian tersebut adalah BP-MLL (Backpropagation for multilabel Learning) yang merupakan algoritma backpropagation dengan menggunakan fungsi error yang menangkap karakteristik pembelajaran multi-label, yaitu label dari suatu instance harus diberi peringkat lebih tinggi daripada yang tidak termasuk dalam instance tersebut. Metode BP-MLL memiliki hasil akurasi yang lebih tinggi dibandingkan metode multi-label lainnya seperti BoosTexter, ADTBoost.MH, Rank-SVM dan BasicBP.

Penelitian klasifikasi teks multi-label juga dilakukan oleh Reynaldi Ananda Pane [8] pada klasifikasi topik ayat Al-Quran terjemahan bahasa Inggris menggunakan Multinomial Naive Bayes, proses stemming dan tanpa stemming mempengaruhi hasil evaluasi yang didapatkan, proses tanpa stemming mendapatkan hasil yang lebih baik karena setiap kata yang terkandung dalam Al-Qur'an memiliki ciri khusus. Hamming loss digunakan sebagai metode untuk evaluasi performansi sistem. Performa terbaik yang didapatkan pada penelitian ini adalah 0.1247 
Disisi lain, terdapat beberapa metode optimasi yang dapat digunakan untuk meningkatkan performasi classifier ANN dan SVM seperti penelitian yang dilakukan oleh Septian N [9] membangun sistem ramalan cuaca menggunakan Hybrid Genetic Algoritm dan Feedforward Neural Network yang terhubung secara parsial. Pada penelitian tersebut, mendapatkan nilai MAPE sebesar 35,20\% atau akurasi sebesar 64,80\% dan MAPE 18,48\% atau $81,52 \%$ untuk nilai data yang hilang pada intensitas hujan diganti dengan nol dan rata-rata. Contoh lain, penelitian yang dilakukan oleh Joko [10] menggunakan Particle Swarm Optimization (PSO) yang diintegrasikan dengan Artificial Neural Network (ANN) dalam memprediksi laju inflasi. Menurut Joko penintegrasian model ANN-PSO digunakan untuk saling mengatasi kelemahan dan meningkatkan kelebihan pada masing-masing model sehingga diperoleh hasil pengukuran yang lebih baik. Hal tersebut terbukti pada pengujian prediksi laju inflasi menunjukkan bahwa secara ANN-PSO atau disebut dengan awPSO-ANN mendapatkan nilai RMSE yang lebih baik (0.157) dibandingkan ANN sebelum dioptimasi (0.181).

\section{ANALISA DAN PEMBAHASAN}

Dataset yang digunakan pada penelitian adalah hadis shahih Bukhari terjemahan bahasa Indonesia sebanyak 1000 data. Pada setiap data diberi label kelas yang terdiri dari tiga kelas yaitu kelas anjuran, kelas larangan, dan kelas informasi. Setiap data dapat memiliki satu atau lebih label kelas. Berikut contoh data yang akan digunakan pada proses klasifikasi yang terdapat pada Tabel 1 berikut.

Tabel 1. Data Hadis Multi-Label

\begin{tabular}{llll}
\hline \multicolumn{1}{c}{ Data } & Anjuran & Larangan & Informasi \\
\hline $\begin{array}{l}\text { Siapa yang Kaum Muslimin selamat dari lisan dan tangannya. } \\
\text { Kamu memberi makan, mengucapkan salam kepada orang yang kamu }\end{array}$ & 1 & 0 & 1 \\
$\begin{array}{l}\text { kenal dan yang tidak kamu kenal. } \\
\text { permudahlah dan jangan persulit, berilah kabar gembira dan jangan } \\
\text { membuat orang lari. }\end{array}$ & 1 & 1 & 1 \\
\hline
\end{tabular}

Pada penelitian ini, sistem dibangun untuk dapat melakukan klasifikasi data hadis terhadap tiga kelas data multi-label seperti yang telah direpresentasikan pada Tabel 1. Ada beberapa proses utama yang dilakukan dalam membangun sistem antara lain: proses preprocessing yaitu proses untuk menghasilkan data yang terstruktur dan bersih, selanjutnya proses feature selection yang digunakan untuk memilih fitur yang berpengaruh, proses pembobotan setiap fitur, proses klasifikasi yang akan menentukan kelas pada setiap data hadis, dan evaluasi dari proses klasifikasi. Berikut secara umum gambaran alur sistem pada Gambar 1.

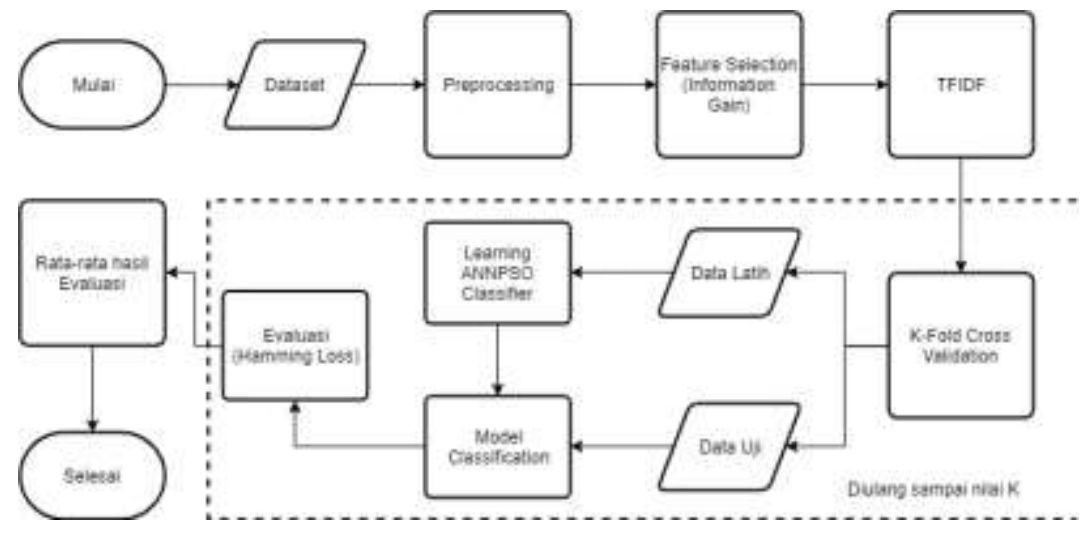

Gambar 1. Gambaran Umum Alur Sistem

Pada tahap awal dilakukan proses preprocessing untuk menghilangkan noise dan mengubah menjadi data hadis menjadi data yang terstruktur sesuai dengan kebutuhan pada proses selanjutnya. Proses preprocessing dibagi menjadi beberapa tahap yang digambarkan pada Gambar 2 .

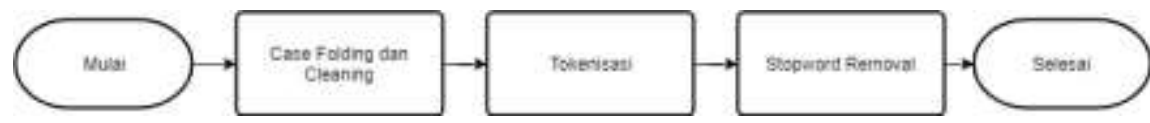

Gambar 2. Tahap Proses Preprocessing

1. Case Folding, merupakan proses untuk mengubah setiap kata menjadi huruf kecil, tahap ini diperlukan karena setiap data hadis terdapat huruf kapital sehingga data menjadi tidak konsisten dan perlu distandarisasikan menjadi huruf kecil. 
2. Cleaning, merupakan proses untuk menghilangkan karakter yang tidak dibutuhkan seperti tanda baca, angka dan simbol.

3. Tokenisasi, merupakan proses memotong kalimat menjadi kumpulan kata-kata yang kemudian setiap kata dijadikan fitur / atribut untuk proses selanjutnya.

4. Stopword Removal, merupakan proses untuk menghilangkan kata-kata yang kurang penting dan frekuensi jumlah kemunculannya cukup sering seperti : dan, atau, nama orang (pada kasus klasifikasi hadis)

Tahap selanjutnya, data yang telah di preprocessing akan diseleksi untuk menentukan fitur mana saja yang akan digunakan untuk proses klasifikasi. Tahap ini disebut juga dengan feature selection, yang dimana hasil dari proses ini sangat mempengaruhi hasil klasifikasi karena akan menentukan fitur/kata apa saja yang berhubungan dengan masing-masing kelas. Feature Selection yang digunakan pada penelitian ini adalah Information Gain (IG). Semakin tinggi kata yang memiliki nilai information gain maka semakin mempengaruhi kelas tersebut dan akan dijadikan fitur utama dalam proses klasifikasi.

$$
I(C ; A)=H(C)-H(C \mid A)
$$

Pada Persamaan(1) Dimana C merupakan kelas dan A adalah atribut (kata), sedangkan $H(C)=$ $-\sum_{C E C} p(C) \log p(C)$ merupakan entropi dari kelas dan $H(C \mid A)=-\sum_{C E C} p(C \mid A) \log p(C \mid A)$ merupakan kondisional entropi dari tiap kelas terhadap setiap kata [6]. Pada kasus ini, probabilitas dari kelas $\mathrm{C}$ antara yang termasuk kedalam kelas $\mathrm{C}$ atau yang tidak termasuk kedalam kelas $\mathrm{C}$ adalah 0.5 , sehingga hasil nilai $H(C)=1$. Oleh karena itu, formula untuk menghitung nilai information gain menjadi :

$$
I(C ; A)=1-H(C \mid A) ;
$$

Semakin tinggi nilai information gain menandakan bahwa kata tersebut berpengaruh pada kelas yang ada. Adapun nilai threshold yang digunakan untuk menentukan batas minimal kata mana saja yang akan diambil dengan cara melihat plot hasil perhitungan seluruh kata pada setiap kelas. Proses selanjutnya yaitu pembobotan kata dengan menggunakan Term Frequency - Inverse Document Frequency atau dikenal dengan sebutan TF-IDF. Pada proses ini data direpresentasikan kedalam sebuah matriks dimana setiap baris pada matriks merupakan dokumen dan untuk kolomnya sebagai kata / fitur (term). Adapun TF(Term Frequency) merupakan frekuensi kemunculan sebuah kata dalam suatu document sedangkan IDF (Inverised Document Frequency) merupakan hubungan ketersediaan sebuah kata dalam keseluruhan dokumen, semakin sedikit jumlah dokumen yang mengandung kata yang dimaksud, maka nilai IDF semakin besar. Berikut persamaan (3) merupakan perhitungan bobot menggunakan TF-IDF :

$$
w_{i j}=t f x i d f=t f_{i j} x \log \frac{D}{d f i}
$$

Dimana :

$w_{i j}=$ bobot kata $t_{j}$ terhadap dokumen $d_{i}$,

$t f_{i j}=$ jumlah kemunculan kata $t_{j}$ dalam dokumen $d_{i}$,

idf = Inversed Document Frequency,

Nilai IDF didapatkan dari IDF $: \log 2\left(\mathrm{D} / d_{f i}\right)$, dimana :

$\mathrm{D}=$ jumlah dokumen,

$d_{f i}=$ banyak dokumen yang mengandung kata yang dicari.

Bobot yang telah didapatkan dari perhitungan akan digunakan sebagai masukkan (input) pada model klasifikasi yang dibangun.

Pada proses selanjutnya adalah tahap pengujian model yang telah dibangun menggunakan $k$-fold cross validation. Dalam teknik ini dataset dibagi menjadi sejumlah K-buah partisi secara acak dan K-jumlah perulangan percobaan, dimana setiap masing-masing percobaan menggunakan data partisi ke-K sebagai data testing dan sisa data pada partisi lainnya digunakan sebagai data training.

Pada penelitian ini digunakan nilai k-fold $=5$. Pada penelitian ini, model klasifikasi yang dibangun adalah feedforward neural network yang bobot dan biasnya dilatih menggunakan particle swarm optimization. Particle Swarm Optimization (PSO) merupakan algoritma Swarm Intelligence, yang didasarkan pada perilaku sekawanan burung. Perilaku sosial ini terdiri dari tindakan individu dan pengaruh dari individu-individu lain dalam suatu kelompok. Setiap individu berperilaku secara terdistribusi dengan kecerdasannya masing-masing dan juga dipengaruhi oleh perilaku kelompok kolektifnya. Pada implementasinya, berikut gambaran proses pencarian solusi dengan menggunakan PSO-FNN : 


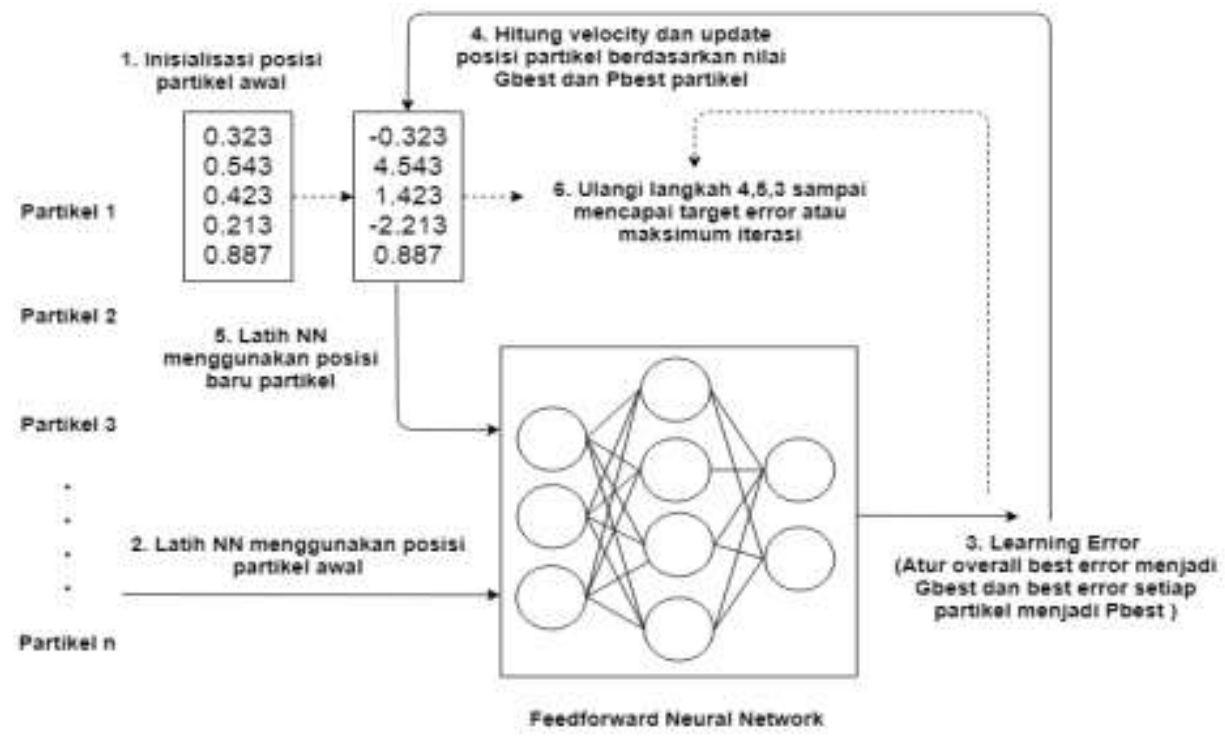

Gambar 3. Proses PSO-FNN

Pencarian solusi dengan menggunakan PSO diawali dengan inisialisasi sekelompok partikel acak yang ditugaskan pada posisi acak particle swarm optimization (bobot dan bias) selanjutkan model klasifikasi dilatih menggunakan posisi partikel awal, perhitungan maju (feedforward neural network) akan menghasilkan kesalahan pembelajaran (partikel fitness) berdasarkan bobot awal dan bias, dan kesalahan pada saat iterasi berlangsung akan dikurangi oleh perubahan posisi partikel, dan akan memperbarui bobot dan bias jaringan. Adapun "pbest" merupakan nilai solusi terbaik yang dimiliki oleh setiap partikel dan "gbest" merupakan nilai solusi terbaik untuk semua partikel yang diterapkan pada persamaan (persamaan 4) untuk melakukan update kecepatan supaya menghasilkan nilai solusi terbaik atau nilai minimal dari target kesalahan pembelajaran. Penetapan posisi baru (nilai bobot dan bias) yang dihasilkan dengan menambahkan nilai kecepatan (persamaan 5) untuk menghasilkan posisi baru untuk pembelajaran baru pada perhitungan maju (feedforward neural network).

Proses tersebut diulang sampai kondisi berhenti atau kesalahan belajar sudah minimum. Hasil dari pembelajaran tersebut merupakan solusi untuk permasalahan optimasi, yang diambil berdasarkan pada nilai posisi "gbest" berupa nilai bobot dan bias.

$$
\begin{gathered}
V_{k+1}=w, V_{k}+c_{1} \cdot R_{1} \cdot\left(\text { Pbest }_{k}-X_{k}\right)+c_{2} \cdot R_{2} \cdot\left(\text { Gbest }_{k}-X_{k}\right) \\
X_{k+1}=X_{k}+V_{k+1}
\end{gathered}
$$

Dimana :

$$
\begin{array}{ll}
k=1,2,3 \text { sampai } N \text { jumlah partikel } & C_{1} C_{2}=\text { nilai learning rates } \\
V_{k}=\text { kecepatan posisi sekarang }(\text { awal }) & R_{1} R_{2}=\text { nilai acak antara } 0 . .1 \\
\text { Pbest }_{k}=\text { nilai personal best } & X_{k}=\text { posisi sekarang (saat ini) } \\
\text { Gbest }_{k}=\text { nilai global best } & w=\text { inertia weight }
\end{array}
$$

Parameter weight pbest $\left(C_{1}\right)$, weight gbest $\left(C_{2}\right)$ yang digunakan pada particle swarm optimization mengacu pada penelitian yang dilakukan oleh Abdul Hamed [11], sedangkan parameter untuk pembobotan (inertia weight) menggunakan nilai default yaitu 1 .

Tabel 2. Parameter PSO

\begin{tabular}{cc}
\hline Parameter & Nilai \\
\hline$C_{1}$ (weight pbest) & 2.0 \\
$C_{2}$ (weight gbest) & 2.0 \\
Inertia weight $(\mathrm{w})$ & 1 (default) \\
Jumlah partikel / populasi & 30 \\
\hline
\end{tabular}

Adapun arsitektur jaringan neural network yang dibagun pada penelitian ini digambarkan pada Gambar 3 dibawah ini : 


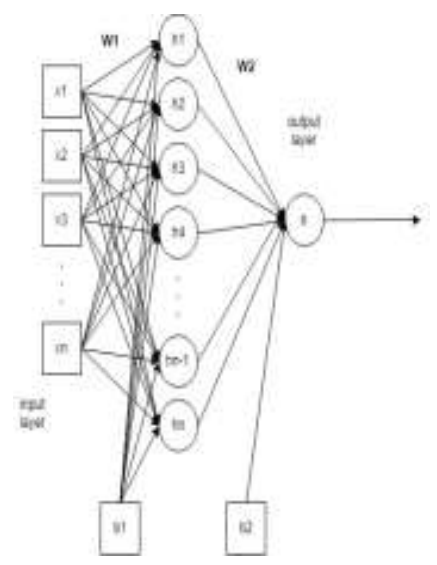

(a) Model Anjuran

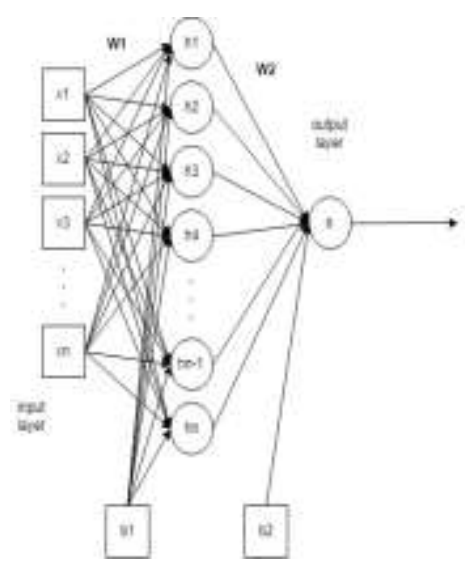

(b) Model Larangan

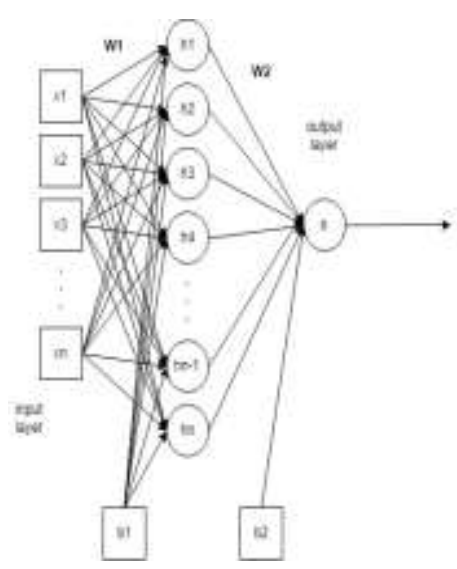

(c) Model Informasi

Gambar 4. Arsitektur Artificial Neural Network untuk Data Multi-Label

Pada Gambar 4 dibangun tiga model arsitektur yang digunakan untuk klasifikasi multi-label. Setiap arsitektur jaringan melatih data pada kelasnya masing-masing, sehingga setiap arsitektur memiliki nilai input dan bobot yang berbeda-beda. Setiap data dilatih dan diuji pada setiap arsitektur apakah data tersebut termasuk kelasnya atau tidak. Parameter yang digunakan pada pelatihan neural network yaitu :

Tabel 3. Parameter Neural Network

\begin{tabular}{cc}
\hline Parameter & Nilai \\
\hline Learning rates & 0.1 \\
Momentum & 0.1 \\
Training Cycle & 1000 \\
Hidden layer & 10 \\
\hline
\end{tabular}

Pada proses terakhir yaitu mengevaluasi sistem yang telah dibangun apakah sudah baik atau belum dari hasil performasi klasifikasi pada data uji. Teknik hamming loss digunakan untuk proses evaluasi pengukuran performansi sistem, teknik ini biasanya digunakan untuk kasus multi-label. Performansi akan semakin baik jika output yang dihasilkan mendekati nilai 0, sehingga semakin kecil nilai hamming loss yang didapatkan maka semakin baik performansi sistem. Berikut pada Persamaan (6) adalah cara menentukan nilai hamming loss

$$
\text { hamming loss }=\frac{1}{N L} \sum_{i=1}^{N} \sum_{j=1}^{L}\left[\hat{y}_{j}^{(i)} \neq y_{j}^{(i)}\right]
$$

Dimana nilai $N$ merupakan banyak data yang diklasifikasikan, $L$ adalah jumlah label kelas, dan $\left[\hat{y}_{j}^{(i)} \neq y_{j}^{(i)}\right]$ merupakan banyaknya kesalahan pada proses klasifikasi. Berikut contoh perhitungan untuk mendapatkan nilai hamming loss.

Tabel 4. Evaluasi Hamming Loss

\begin{tabular}{|c|c|c|c|c|c|c|}
\hline & \multicolumn{3}{|c|}{$y^{(i)}$} & \multicolumn{3}{|c|}{$\widehat{y}^{(i)}$} \\
\hline & Anjuran & Larangan & Informasi & Anjuran & Larangan & Informasi \\
\hline Hadis $1 \tilde{x}^{(1)}$ & 1 & 1 & 0 & 1 & 1 & 1 \\
\hline Hadis $2 \tilde{x}^{(2)}$ & 1 & 0 & 1 & 1 & 0 & 1 \\
\hline Hadis $3 \tilde{x}^{(3)}$ & 1 & 1 & 1 & 1 & 0 & 1 \\
\hline Hadis $4 \tilde{x}^{(4)}$ & 1 & 0 & 0 & 1 & 0 & 0 \\
\hline Hadis $5 \tilde{x}^{(5)}$ & 0 & 1 & 0 & 0 & 1 & 0 \\
\hline
\end{tabular}

Terdapat 2 kesalahan pada proses evaluasi sehingga jika jumlah data $(\mathrm{N})=5$ dan label kelas $(\mathrm{L})=3$ maka nilai hamming loss yang didapatkan adalah $1 /(5 * 3) * 2=0.1333$

\section{IMPLEMENTASI}

Untuk mengetahui performansi yang dihasilkan pada feedforward neural network yang bobot dan biasnya telah dilatih menggunakan particle swarm optimization, dilakukan evaluasi terhadap beberapa skenario pengujian. Pengujian pertama dilakukan untuk mengetahui pengaruh dari penggunaan proses stemming pada data hadis Bukhari terjemahan bahasa Indonesia. Pengujian kedua dilakukan untuk mengetahui pengaruh perubahan jumlah partikel pada particle swarm optimization berdasarkan nilai hamming loss yang didapatkan, dan Pengujian terakhir 
dilakukan komparasi antara backpropagation - feedforward neural network (BP-FNN) dengan particle swarm optimization - feedforward neural network (PSO-FNN) untuk mengetahui nilai hamming loss dan waktu komputasi yang didapatkan dengan menggunakan data hadis yang telah di-stemming dan yang tidak.

1. Skenario Pengujian dengan Proses Stemming

Dilakukan skenario pengujian untuk mendapatkan nilai hamming loss dari model PSO-FNN dengan membandingkan hasil yang didapatkan dari data hadis yang telah diproses stemming dan yang tidak, pengujian dilakukan sebanyak k-fold $=5$. Hasil pengujian dapat dilihat pada Tabel 5.

Tabel 5. Hasil skenario pengujian dengan proses stemming

\begin{tabular}{lcrc}
\hline \multicolumn{1}{c}{ Pengujian } & $\begin{array}{c}\text { Iterasi K- } \\
\text { Fold ke : }\end{array}$ & $\begin{array}{c}\text { Hamming } \\
\text { Loss }\end{array}$ & $\begin{array}{c}\text { Rata-rata } \\
\text { Hloss }\end{array}$ \\
\hline Stemming & 1 & 0.1183 & \\
& 2 & 0.15 & 0.1205 \\
& 3 & 0.126 & \\
& 4 & 0.093 & \\
Tanpa Stemming & 5 & 0.115 & \\
& 1 & 0.1183 & 0.1143 \\
& 2 & 0.135 & \\
& 3 & 0.1083 & \\
& 4 & 0.0917 & \\
& 5 & 0.1183 & \\
\hline
\end{tabular}

Dari hasil yang telah didapatkan, proses klasifikasi dengan tanpa proses stemming mendapatkan hasil ratarata nilai hamming loss yang lebih baik dibandingkan dengan proses stemming yaitu sebesar 0.114 atau $88.57 \%$ data berhasil di klasifikasikan dengan benar, selisih 0.62 dari klasifikasi dengan proses stemming. Hal ini menunjukkan bahwa setiap kata pada hadis Bukhari yang di stemming akan menghilangkan makna atau ciri dari kata tersebut, imbuhan akhiran "-lah" biasanya merujuk pada ajakan atau larangan sehingga jika menggunakan stemming sulit membedakan antara maksud dari "shalat" dan "shalat-lah".

2. Skenario Pengujian jumlah partikel pada Particle Swarm Optimization

Pada skenario ini dilakukan tiga pengujian terhadap jumlah partikel pada particle swarm optimization. Hal ini untuk mengetahui seberapa besar pengaruh perbedaan jumlah partikel terhadap hasil hamming loss yang didapatkan. Jumlah partikel menentukan banyaknya solusi yang dihasilkan oleh model particle swarm optimization, Nilai bobot dan bias terbaik "gbest" yang dihasilkan dari partikel, kemudian digunakan menjadi parameter bobot dan bias feedforward neural network untuk data testing. Jumlah partikel yang diuji pada skenario ini yaitu 10, 30, dan 50 .

Tabel 6. Hasil skenario pengujian jumlah partikel

\begin{tabular}{ccrc}
\hline $\begin{array}{c}\text { Jumlah Partikel } \\
\text { PSO }\end{array}$ & $\begin{array}{c}\text { Iterasi K- } \\
\text { Fold ke : }\end{array}$ & Hamming Loss & $\begin{array}{c}\text { Rata-rata } \\
\text { Hloss }\end{array}$ \\
\hline 10 & 1 & 0.12 & 0.1186 \\
& 2 & 0.145 & \\
& 3 & 0.1083 & \\
& 4 & 0.0967 & \\
& 5 & 0.1233 & \\
& 1 & 0.1167 & 0.1143 \\
& 2 & 0.135 & \\
& 3 & 0.11 & \\
& 4 & 0.0933 & \\
& 5 & 0.1167 & \\
& 1 & 0.1167 & \\
& 2 & 0.1367 & \\
& 3 & 0.1083 & \\
& 4 & 0.0917 & \\
& 5 & 0.1167 & \\
& & & \\
& & &
\end{tabular}

Dari hasil yang didapatkan pada Tabel 6, jumlah 50 partikel pada particle swarm optimization mendapatkan hasil rata-rata nilai hamming loss sebesar 0.114 atau 88.6\%, lebih baik dibandingkan dengan menggunakan 10 dan 30 partikel. Pada pengujian ini semakin banyak jumlah partikel maka semakin baik model yang dibangun. Hal tersebut dikarenakan semakin banyak jumlah partikel maka semakin banyak solusi pada setiap partikel yang mungkin dihasilkan oleh particle swarm optimization, kemudian dari banyak solusi tersebut dipilih solusi terbaiknya "gbest" yang akan dijadikan sebagai bobot dan bias pada model feedforward neural network untuk pengujian data testing.

3. Skenario pengujian komparasi PSO-FNN dan BP-FNN. 
Pada skenario ini akan diuji performansi dari feedforward neural network yang bobot dan biasnya dilatih menggunakan particle swarm optimization (PSO-FNN) dan backpropagation - feedforward neural network(BP-FNN) berdasarkan hasil dari evaluasi hamming loss. Pada pengujian ini, masing-masing classifier menggunakan parameter yang telah ditentukan, untuk PSO-FNN menggunakan partikel sebanyak 30, sedangkan pada BP-FNN nilai learning rate sebesar 0.1. Pengujian dilakukan menggunakan dataset yang telah di-stemming dan yang tidak. Berikut Tabel 7 merupakan hasil pengujian dari skenario tiga.

Tabel 7. Skenario Pengujian Performansi BPNN+PSO dan BPNN

\begin{tabular}{|c|c|c|c|c|}
\hline Model Classifier & Pengujian & $\begin{array}{l}\text { Iterasi K- } \\
\text { Fold ke : }\end{array}$ & Hamming Loss & $\begin{array}{c}\text { Rata-rata } \\
\text { Hloss }\end{array}$ \\
\hline \multirow{10}{*}{ PSO-FNN } & Stemming & 1 & 0.1183 & \multirow{3}{*}{0.1205} \\
\hline & & 2 & 0.15 & \\
\hline & & 3 & 0.126 & \\
\hline & & 4 & 0.093 & \multirow{7}{*}{0.1143} \\
\hline & & 5 & 0.115 & \\
\hline & Tanpa Stemming & 1 & 0.1183 & \\
\hline & & 2 & 0.135 & \\
\hline & & 3 & 0.1083 & \\
\hline & & 4 & 0.0917 & \\
\hline & & 5 & 0.1183 & \\
\hline \multirow{10}{*}{ BP-FNN } & Stemming & 1 & 0.1483 & \multirow{4}{*}{0.1183} \\
\hline & & 2 & 0.115 & \\
\hline & & 3 & 0.0983 & \\
\hline & & 4 & 0.1033 & \\
\hline & & 5 & 0.1267 & \multirow{6}{*}{0.105} \\
\hline & Tanpa Stemming & 1 & 0.1333 & \\
\hline & & 2 & 0.1016 & \\
\hline & & 3 & 0.0867 & \\
\hline & & 4 & 0.0917 & \\
\hline & & 5 & 0.1117 & \\
\hline
\end{tabular}

Dari hasil pengujian pada setiap model klasifikasi baik itu particle swarm optimization - feedforward neural network ataupun backpropagation - feedforward neural network pada data yang tidak menggunakan proses stemming memiliki hasil hamming loss lebih baik dibandingkan dengan proses stemming. Selain itu, pada studi kasus ini performansi particle swarm optimization - feedforward neural network hanya mendapatkan akurasi sebesar $88.57 \%$, lebih rendah dibandingkan backpropagation - feedforward neural network dengan selisih $0.93 \%$.

\section{KESIMPULAN}

Berdasarkan pengujian yang dilakukan pada tiga skenario yang berbeda, pada penerapan particle swarm optimization (PSO) untuk melatih bobot dan bias pada feedforward neural network (PSO-FNN), jumlah partikel pada PSO mempengaruhi hasil hamming loss dari klasifikasi. Hal tersebut dikarenakan semakin banyak jumlah partikel maka semakin banyak solusi pada setiap partikel yang dihasilkan untuk menentukan bobot terbaik yang akan digunakan oleh model FNN pada pengujian data testing. Pada dataset hadis Bukhari proses klasifikasi tanpa proses stemming mendapatkan hasil yang lebih baik, karena setiap kata pada hadis Bukhari yang tidak di-stemming tidak akan menghilangkan makna atau ciri dari kata tersebut, dengan kata lain setiap kata yang terdapat imbuhan dapat mempengaruhi sifat dari hadis tersebut.

Pada pengujian ini performansi yang dihasilkan metode particle swarm optimization - feedforward neural network tidak lebih baik dibandingkan dengan backpropagation - feedforward neural network. Sehingga perlu dilakukan penelitian lebih lanjut dengan menggunakan metode optimasi lainnya seperti Genetik Algorithm (GA), Ant Colony Optimization (ACO), Cuckoo Optimization Algorithm (COA).

\section{REFERENCES}

[1] Adiwijaya, Aulia, M.N., Mubarok, M.S., Novia, W.U. and Nhita, F. A comparative study of MFCC-KNN and LPC-KNN for hijaiyyah letters pronounciation classification system. Information and Communication Technology (ICoIC7), 5th International Conference on pp. (pp. 1-5). 2017.

[2] M. N. Al-Kabi, G. Kanaan, R. Al-Shalabi, S. Al-Sinjilawi and R. S. Al-Mustafa. Al-Hadith Text Classifier. Journal of Applied Sciences 5, pp. 584-587. 2005.

[3] F. Harrag and E. El-Qawasmah. Neural Network for Arabic Text Classification. 2009 Second International Conference on the Applications of Digital Information and Web Technologies, pp. 778-783. 2009. 
[4] liza Riviera R. J, Said Al-Faraby, Adiwijaya. Klasifikasi Anjuran, Larangan dan Informasi pada Hadis Sahih Al-Bukhari. e-Proceeding of Engineering, p. 4683. 2017.

[5] Andina K., Said Al-Faraby, Adiwijaya. Klasifikasi Informasi, Anjuran dan Larangan pada Hadits Shahih Bukhari menggunakan Metode Support Vector Machine. e-Proceeding of Engineering, p. 5014. 2017.

[6] Asriyanti I. P \& Adiwijaya. On the Feature Selection and Classification Based on Information Gain for Document Sentiment Analysis. Applied Computational Intelligence and Soft Computing, vol. 2018, p. 5. 2018.

[7] Min-Ling Zhang \& Zhi-Hua Zhou. Multilabel neural networks with applications to functional genomics and text. IEEE transactions on Knowledge and Data Engineering, pp. 1338-1351. 2006.

[8] Reynaldi A. P., Mubarok M. S., Nanang S. H., Adiwijaya, A Multi-lable Classification on Topics of Quranic Verses in English Translation using Multinomial Naive Bayes. 6th International Conference on Information and Communication Technology (ICoICT). 2018.

[9] S. a. N. F. Nurcahyo. Rainfall Prediction in Kemayoran Jakarta Using Hybrid Genetic Algorithm (GA) and Partially Connected Feedforward Neural Network (PCFNN). Information and Communication Technology (ICoICT), pp. 166-171. 2014

[10] Joko S. Dwi Raharjo. Model Artificial Neural Network berbasis Particle Swarm Optimization untuk Prediksi Laju Inflasi. Sistem Komputer. 2013.

[11] H. N. Abdull Hamed, Siti Mariyam S. and Naomie Salim. Particle Swarm Optimization For Neural Network Learning Enchancement. Jurnal Teknologi, pp. 13-26. 2008.

[12] A. Ethem, "Introduction to Machine Learning," MIT Press, 2010

[13] Y. H. Zweiri, J. F. Whidborne, L. D. Seneviratne. A three-term backpropagation algorithm. Neurocomputing, pp. 305-318. 2003.

[14] S. M. Suyanto, in Artificial Intelligence: Searching, Reasoning, Planning and Learning, Bandung, Informatika. 2014.

[15] Al Mira K. I., Mubarok M. S., Nanang S. H., Adiwijaya. A Multi-label Classification on Topics of Quranic Verses in English Translation Using Tree Augmented Naïve Bayes. 6th International Conference on Information and Communication Technology (ICoICT). 2018.

[16] Mubarok, M.S., Adiwijaya and Aldhi, M.D. Aspect-based sentiment analysis to review products using Naïve Bayes. AIP Conference Proceedings (Vol. 1867, No. 1, p. 020060). 2017. 